\title{
Shallow groundwater quality in Latvia and Denmark
}

\author{
Edmund Gosk, lgors Levins and Lisbeth Flindt Jørgensen
}

Experience and results from the Danish groundwater monitoring programme that has been carried out systematically since 1990, have been used in a co-operative project between Latvia and Denmark. The main objective of the project was to obtain more detailed knowledge of the shallow Latvian groundwater, to optimise the Latvian groundwater monitoring programme and to support the implementation of European legislation such as the Water Framework Directive, the Nitrate Directive and the Groundwater Directive in Latvia.

Comprehensive summaries describing the methodology of groundwater quality monitoring as well as the major results from the Danish groundwater monitoring network can be found in GEUS (2005) and Stockmarr (2005). Until recently only few data on Latvian groundwater quality were available, but in a project running from 2003 to 2006, 800 samples from groundwater, springs and drains have been analysed for a large number of components resulting in a comprehensive overview of the status of Latvian groundwater (Fig. 1; Gosk et al. 2006).
The project Agricultural influence on groundwater in Latvia was carried out by the State Geological Survey of Latvia and the Geological Survey of Denmark and Greenland (GEUS) and was supported by the Danish Environmental Protection Agency within the framework of the DANCEE programme (Danish Co-operation for Environment in Eastern Europe). As a spin-off of the project this paper compares groundwater quality in the two countries.

\section{Groundwater use and agricultural load}

Drinking-water production in Denmark is almost entirely based on groundwater abstracted from both shallow and moderately deep Quaternary and pre-Quaternary aquifers covered by more or less protective layers of till of variable thickness.

The annual groundwater recharge is relatively large in Denmark and is on an average, national scale sufficient to cover needs (Henriksen \& Sonnenborg 2003). However,

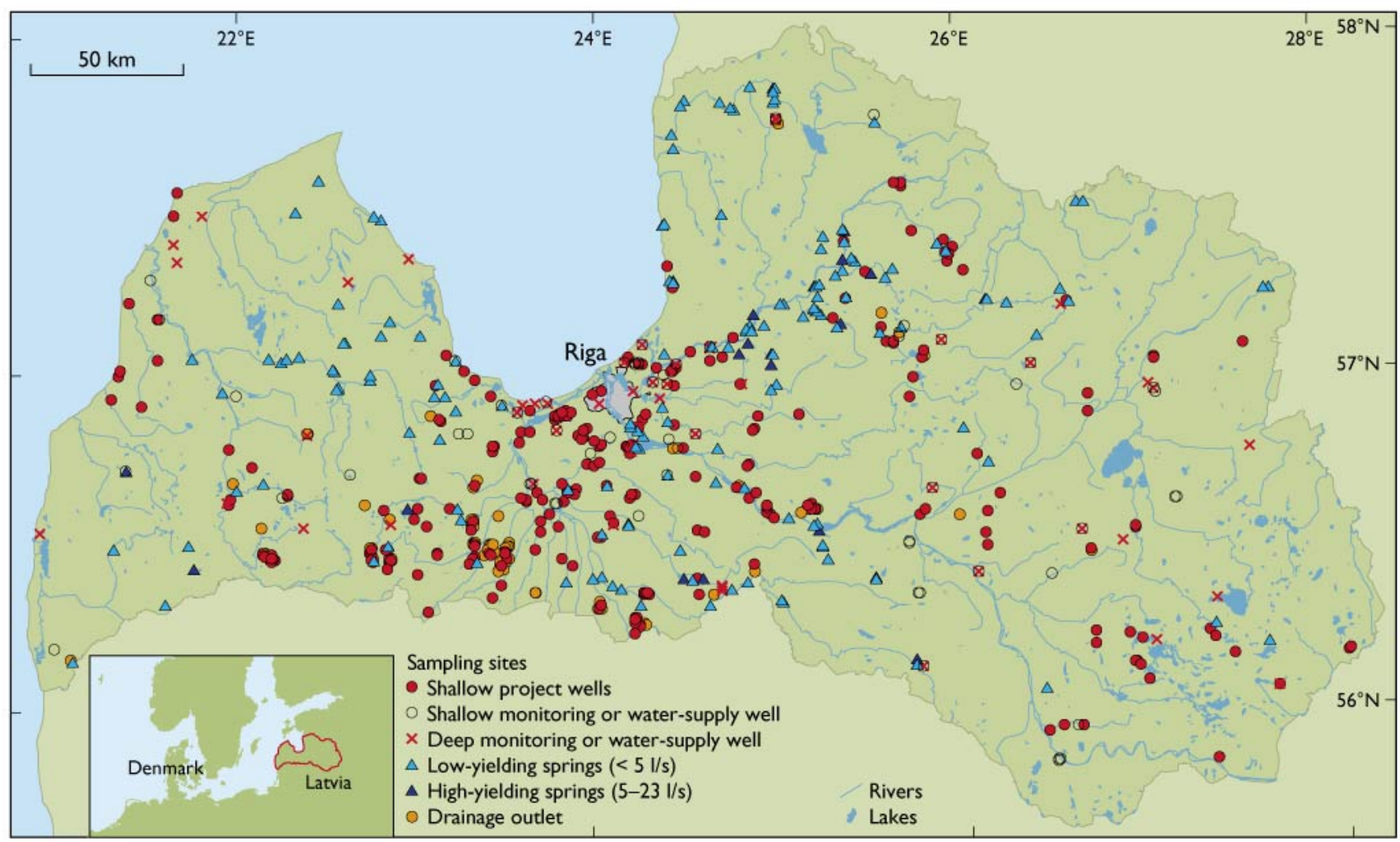

Fig. 1. Sampling sites of Latvian groundwater. 
abstraction exceeds recharge in some areas, especially around the largest cities. Furthermore, diffuse groundwater contamination by pesticides and nitrate has become an increasing problem since the middle of the last century, and a number of water-supply wells have been closed. Up to now it has been possible to find new, clean groundwater resources, either by drilling deeper wells or by moving wells to less impacted areas.

More than $60 \%$ of the Danish territory is defined as arable land. The impact of agriculture on water quality has been known for many years, and measures aiming at a reduction of nutrient load started in the 1980s with the adoption of the first Action Plan on the Aquatic Environment. At that time the average nitrogen load had reached $130 \mathrm{~kg} \mathrm{~N} / \mathrm{ha}$, which resulted in a high risk of groundwater contamination and in actual quality problems in some areas of the country.

Drinking-water production in Latvia is also primarily based on groundwater. Only Riga Water Supply uses a substantial amount of surface water to produce about half of the drinking water consumed in the Latvian capital.

The thick till layer that covers most of Latvia is characterised by poor aquifer conditions where only little groundwater abstraction is possible from small, local water-bearing lenses. The centralised drinking-water supply in Latvia is therefore typically based on confined aquifers screened at depths greater than $50 \mathrm{~m}$. In areas with intensive agriculture (the southern and central parts of the country) the average depth of wells exceeds $100 \mathrm{~m}$.

Due to the dramatic political and economical changes in Latvia at the beginning of the 1990s groundwater abstraction decreased by a factor of 2-3 resulting in a significant, still progressing recovery of groundwater levels in the central and south-western parts of the country. In the remaining parts of the country groundwater levels have never been affected by abstraction.

During the same period, the acreage of arable crops, the use of mineral fertilisers, the number of livestock and other parameters related to agricultural load, decreased by a factor of 3-10 (Stålnacke et al. 2003). At present only 13\% of the Latvian area is under cultivation, and the average crop yield is about half of the Danish figures.

\section{Groundwater monitoring and knowledge of diffuse contamination}

Due to the pressure from diffuse sources, groundwater monitoring plays an important role in water management and protection of groundwater resources in Denmark. More than 6000 drinking-water supply wells, a network of more than 1400 specially selected screens in 70 groundwater monitoring areas, as well as five agricultural watershed monitoring areas equipped with a total of about 100 shallow screens (Stockmarr 2005), together form the basis of the Danish groundwater monitoring system. The detailed groundwater quality monitoring includes analyses of 97 elements, comprising 14 heavy metals and 34 pesticides and their metabolites (NERI 2005).

The regional groundwater quality monitoring network in Latvia, established in the 1970s and 1980s, is based on 150 wells located within 45 monitoring stations. This network was designed to control depression cones (quantitative monitoring) rather than to monitor the various forms of diffuse pollution (qualitative monitoring). Monitoring wells are typically screened in deep aquifers used for abstraction. Until recently, the parameters analysed comprised major ions and nitrogen compounds, but no analyses of heavy metals and pesticides were made. Groundwater quality data from abstraction wells consisted mainly of information collected during drilling.

Monitoring of drinking-water quality in Latvia is almost entirely limited to sampling of tap water. Although some of the larger water-supply companies collect samples from abstraction wells, the centralised data processing system for this type of analysis is not yet established.

The amount of groundwater data recently collected in Latvia is much smaller than comparable data collected in Denmark. However, a large amount of information on the youngest groundwater in shallow aquifers has been collected in the period 2003-2005 as part of the present project. About 800 groundwater samples were analysed for a wide spectrum of elements, including heavy metals and pesticides (Gosk et al. 2006).

The determination of background concentration of various elements was based on data from shallow wells located outside local point-pollution plumes and urbanised and industrial areas.

\section{Nitrates and pesticides}

As expected, the distribution of nitrates in Danish and Latvian groundwater differs considerably (Fig. 2A). In the shallowest groundwater, the concentration of nitrates exceeds the quality standards of drinking water $\left(50 \mathrm{mg} / \mathrm{NO}_{3}\right)$ in $15 \%$ and $3.5 \%$ of the monitoring screens in Danish and Latvian wells, respectively. Furthermore, the decrease of nitrate concentration with depth is much faster in the Latvian than in the Danish groundwater.

The differences observed are caused by a lower agricultural load in Latvia as well as by a higher denitrification potential and confinement degree of Latvian aquifers and aquitards (Fig. 2B). A statistical comparison of the groundwater residence times is impossible due to the very limited number of 
Fig. 2. A: Distribution of nitrate in Danish and Latvian wells compared to screen depth. Danish data from 719 monitoring screens averaged for the period 1998-2003. Latvian data from 717 monitoring and water-supply wells averaged for the period 2000-2005. B: Distribution of dissolved oxygen in Danish and Latvian wells as a function of screen depth. Danish data from 706 monitoring screens are averaged for the period 1998-2003. Latvian data from 160 monitoring and investigative screens are averaged for the period 2003-2005.

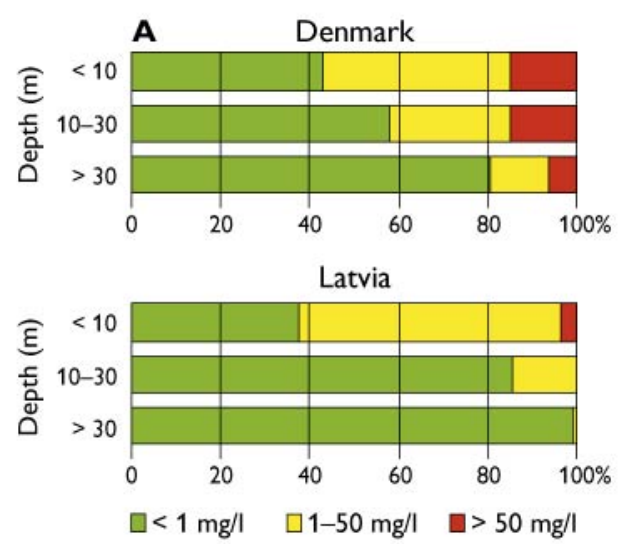

Nitrate
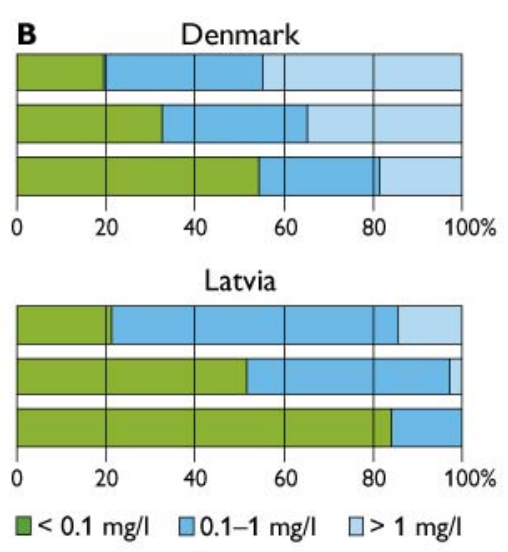

Oxygen age determinations of Latvian groundwater (27 water samples were analysed by the CFC method). However, it seems that Latvian groundwater is about twice as old as Danish groundwater from the same depth.

The recent investigations in Latvia revealed some unexpected results with respect to nitrate in shallow aquifers. Latvian springs capturing the youngest and the most mobile part of groundwater flow seem to be characterised by higher average nitrate concentrations compared to shallow wells drilled to the same aquifers (Fig. 3). Even springs located within areas without obvious nitrate load show persistently higher nitrate concentrations than neighbouring wells. After recognition of this phenomenon several high-yielding springs have been included in the groundwater monitoring network to better understand flow patterns and problems of diffuse nitrate pollution.

Investigations of contamination of Latvian groundwater by pesticides have only just started, and the extent of this problem is not fully clear. Vulnerable areas were identified in the project, and 111 groundwater samples from wells in these areas were analysed for a number of expected pesticides. In $30 \%$ of the samples, concentrations of pesticides exceeded the quality standards of drinking water $(0.1 \mu \mathrm{g} / \mathrm{l})$. This figure

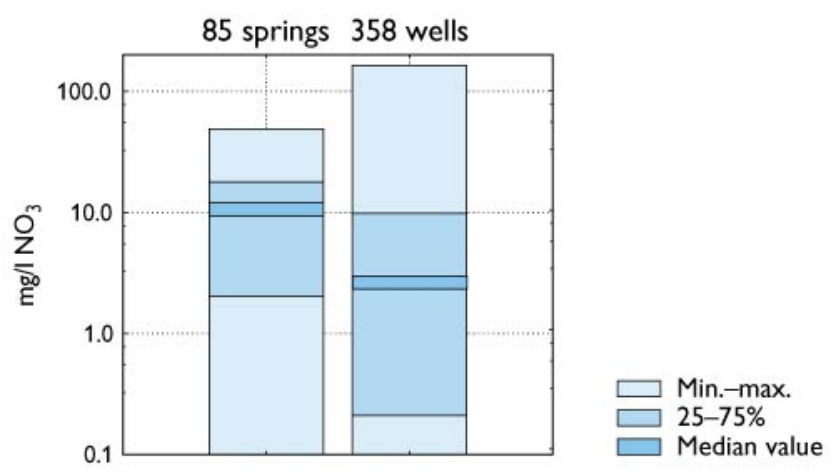

Fig. 3. Distribution of nitrate in 85 springs and 358 shallow wells within Latvian agricultural areas. is identical to the frequency in shallow Danish monitoring screens (Stockmarr 2005). In Denmark the most often found pesticide is BAM (2,6-dichlorobenzamide), a metabolite from dichlobenil and chlorothiamide that prior to 1997 was commonly used as a total herbicide in urban areas, along roads, railways and at farm yards. The triazine group is the second most found pesticide group, but in Latvia this group comes in third place, after the chlorophenoxy acids and trichloroacetic acid (TCA); the latter was the most widely utilised herbicide during the Soviet time and a by-product from the chemical industry.

As the investigation was focused on potentially vulnerable areas and in the uppermost aquifers, an estimate of $30 \%$ occurrence of pesticides is highly pessimistic if the entire Latvian groundwater is considered. Taking into account the smaller acreage of treated areas and a higher confinement degree of main aquifers, the risk of contamination of water-supply wells by pesticides in Latvia should be significantly lower than in Denmark. However, as the pesticides were mainly used in the 1980s they may not yet have reached the main Latvian aquifers containing groundwater older than 50 years.

\section{Minor elements}

In order to compare Danish and Latvian shallow groundwater chemistry, distribution curves of twelve selected minor elements are presented in Fig. 4.

Shallow Latvian groundwater is characterised by higher background concentrations of aluminium and fluoride and lower concentrations of bromide, lithium, manganese, phosphorus and strontium when compared to the Danish data. A majority of the observed differences reflect the difference in basic groundwater chemistry: the median values of the chloride, sulphate and permanganate indices in the Danish data set $(30,45$ and $3.1 \mathrm{mg} / \mathrm{l}$, respectively) are significantly higher than the corresponding values for the Latvian data set $(10,20$ and $1.4 \mathrm{mg} / \mathrm{l}$, respectively). 


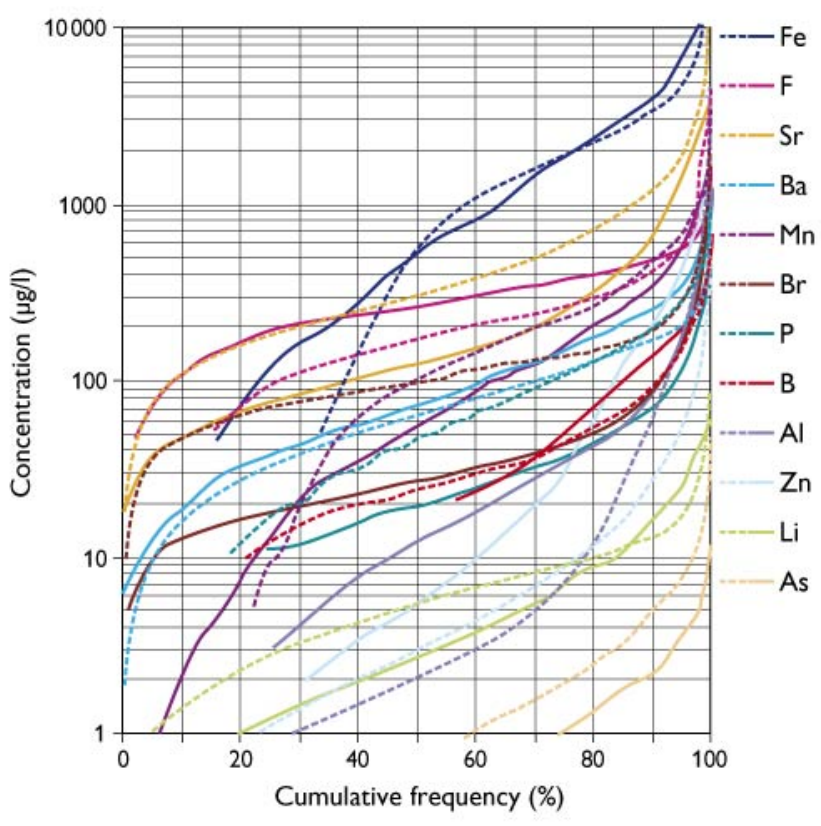

Fig. 4. Distribution of selected minor elements in shallow Latvian groundwater (full lines indicate data from 477 wells and springs for the period 2003-2005) and in shallow Danish groundwater (dotted lines indicate data from 723 monitoring screens for the period 1998-2003).

The anoxic and neutral conditions in the majority of Latvian aquifers are unfavourable for migration of most heavy metals, whose concentrations are well below the quality standards of drinking water. Exceptions are manganese and arsenic that migrate in reducing environments. The concentrations of these elements exceed the quality standards ( 50 and $10 \mu \mathrm{g} / \mathrm{l}$, respectively) in $22 \%$ and $1 \%$ of the samples. Boron and selenium exceed the quality standards (300 and $10 \mu \mathrm{g} / \mathrm{l}$, respectively) only in saline groundwater, where the concentrations of sulphate or chloride are significantly higher than quality standards for drinking water. In general, heavy metals in Latvian groundwater are a smaller problem than in Denmark where manganese and arsenic exceed quality standards of drinking water in $63 \%$ and $9 \%$ of the monitoring screens, respectively. However, these compounds do not pose a problem for the drinking-water supply in general in Denmark due to sorption in natural sand filters at the watertreatment plants.

In Latvia, nickel concentrations higher than the quality standard of drinking water $(20 \mu \mathrm{g} / \mathrm{l})$ were not observed in groundwater below $10 \mathrm{~m}$. In Denmark, high nickel concentrations locally create problems where large-scale depression cones in the groundwater table result in oxidation of sulphide minerals. Lowering of the groundwater table in Latvian aquifers occurs only in deep, confined aquifers rather than in the vicinity of the groundwater table.

\section{Conclusions}

The distribution patterns of minor elements in Latvian and Danish groundwater are somewhat similar and are governed by the basic groundwater chemistry. In general, the background concentrations of aluminium and fluoride are higher, and the concentrations of bromide, lithium, manganese, phosphorus and strontium are lower in shallow groundwater in Latvia compared to the Danish aquifers.

The lower anthropogenic pressure combined with a higher confinement degree of major water-supply aquifers explains why diffuse contamination of Latvian groundwater is lower than in Denmark. At present, the limited data on pesticides and on the age of groundwater do not allow an assessment of the extent of the pesticide problem in Latvian groundwater with sufficient accuracy.

\section{Acknowledgements}

Our much appreciated friend and colleague, Edmund Gosk, passed away on 24 November 2006 after a long struggle against cancer. We wish to acknowledge his engaged involvement in this project in Latvia, as well as in his many other tasks.

\section{References}

GEUS 2005: Grundvand 2004. Status og udvikling 1989-2004. København: Danmarks og Grønlands Geologiske Undersøgelse (in Danish with English summary). Available on: www.geus.dk/publications/grundvandsovervaagning/1989_2004/index.html

Gosk, E., Levins, I. \& Jørgensen, L.F. 2006: Agricultural influence on groundwater in Latvia. Danmarks og Grønlands Geologiske Undersøgelse Rapport 2006/85, 98 pp.

Henriksen, H.J. \& Sonnenborg, A. (eds) 2003: Ferskvandets kredsløb. NOVA 2003 temarapport, 230 pp. København: Danmarks og Grønlands Geologiske Undersøgelse, Danmarks Miljøundersøgelser, Danmarks Jordbrugsforskning and Danmarks Meteorologiske Institut (in Danish with English summary)

Also available on: http://vandmodel.dk/ferskvands_2003_final.htm

NERI 2005: NOVANA - National monitoring and assessment programme for the aquatic and terrestrial environment. Programme description, part 2. NERI Technical Report 537/2005, 137 pp.

Stålnacke, P., Grimvall, A., Libiseller, C., Laznik, M. \& Kokoite, I. 2003: Trends in nutrient concentrations in Latvian rivers and the response to the dramatic change in agriculture. Journal of Hydrology 283, 184- 205. Stockmarr, J. 2005: Groundwater quality monitoring in Denmark. Geological Survey of Denmark and Greenland Bulletin 7, 33-36.

\section{Authors' addresses}

L.F.J. \& E.G. (deceased), Geological Survey of Denmark and Greenland, Øster Voldgade 10, DK-1350 Copenhagen K, Denmark. E-mail: lfj@geus.dk I.L., Latvian Environment, Geology and Meteorology Agency (LEGMA), Maskavas Str. 165, LV-1019 Riga, Latvia. 